\title{
ANAK PESISIR BELAJAR IPA (STUDI ETNOGRAFI ATAS POTENSI DAN HAMBATAN KULTURAL ANAK SUMENEP BELAJAR IPA)
}

\author{
Habibi, Dyah Ayu Fajarianingtyas. \\ Program Studi Pendidikan IPA Universitas Wiraraja Sumenep \\ e-mail: habibi_bk@yahoo.com
}

\begin{abstract}
ABSTRAK
Penelitian ini bertujuan untuk mengeksplorasi bagaimana kondisi budaya di kabupaten sumenep yang dapat memberikan dukungan atau hambatan terhadap proses belajar anak pesisir dalam bidang IPA. Jenis penelitian ini adalah kualitatif etnografis, dimana data diperoleh melalui dua teknik yaitu Observasi dan Wawancara. Peneliti dibantu oleh informan kunci (key informant), diambil dari anggota asli masyarakat yang menjadi obyek penelitian. Hasil dari penelitian ini menunjukkan bahwa kehidupan anak pesisir di Sumenep membentuk suatu pola aktivitas yang sesuai dengan ritme profesi orang tuanya. Dalam hal ini umumnya adalah sebagai petani garam, nelayan, peternak atau petani tembakau). Porsi aktivitas belajar anak pesisir (dalam hal ini belajar IPA) masih minim. Umumnya belajar di rumah baru dilakukan ketika anak-anak mendapat tugas (PR) dari gurunya.
\end{abstract}

Kata kunci: Anak pesisir, Belajar IPA, Etnografi.

\section{PENDAHULUAN}

Kabupaten Sumenep secara geografis memiliki luas daratan 2.092,46 $\mathrm{Km}^{2}$ yang terbagi atas 27 kecamatan. Dari luas daratan ini terdapat 126 pulau, dimana 48 pulau berpenghuni sedangkan sisanya 78 pulau tidak berpenghuni (BPS Sumenep, 2009). Berdasarkan kondisi geografis ini saja kita dapat mengambil suatu gambaran singkat bahwasannya budaya masyarakat Sumenep sebagian besar adalah budaya pesisir. Kondisi budaya Sumenep yang selama ini dieksplorasi umumnya masih mengenai tradisi keislaman, arsitektur bangunan, harga diri (termanifestasi dalam peristiwa carok) serta kehidupan ekonomi-politik (Subariyanto dkk, 2004). Bagaimana potensi dan hambatan budaya yang dimiliki oleh anak-anak Sumenep dalam belajar dan khususnya mendalami bidang IPA membutuhkan suatu proses eksplorasi dan penelitian tersendiri yang bersifat mendalam dan kualitatif.

$$
\text { Mengeksplorasi bagaimana }
$$

budaya lokal melingkupi kehidupan dan belajar anak dapat menjadi langkah efektif untuk membangun dan mengembangkan pembelajaran IPA yang bermakna. Permasalahan dan potensi budaya merupakan bahan mentah bagi penyusunan strategi dan metode pembelajaran IPA yang sesuai bagi siswa, dalam hal ini pada sekolah-sekolah di Sumenep.

Budaya merupakan way of life dari suatu masyarakat, lebih lengkapnya Albrow (1999) menyebutkan budaya sebagai way of thinking, acting and feeling which are transmitted through learning. Transfer budaya dengan jelas disebutkan adalah melalui suatu proses yang disebut dengan belajar. Dengan kata lain, belajar adalah sesuau yang sangat penting bagi keberlangsungan sebuah budaya, artinya budaya dan belajar sebenarnya tidak dapat dipisahkan.

Belajar menurut Albert Bandura banyak terjadi melalui proses modeling, yaitu mencontoh dari seorang model. Seorang anak akan belajar untuk melakukan berbagai macam aktivitas 
dengan mencontoh perilaku orang tuanya. Dalam hal ini orang tua menjadi model sosial bagi seorang anak. Bahkan menurut Bandura, dengan hanya mengamati seorang model, kecenderungan untuk melakukan peniruan akan terjadi walaupun tidak diniatkan. Hal tersebut dikarenakan manusia di dalam dirinya memiliki karakter dasar untuk melakukan belajar melalui peniruan (Halpern \& Donaghey, 2005).

Vygotsky juga memberikan penekanan terhadap landasan proses sosial dalam teorinya mengenai belajar. Menurut Vygotsky proses belajar umumnya terjadi melalui proses komunikasi sosial. Dalam proses ini seorang anak akan melakukan proses belajar secara optimal melalui sebuah pembimbingan yang tepat. Bimbingan yang tepat memiliki arti bantuan yang diberikan oleh seorang pembimbing adalah bersifat seperlunya, menurut Vygotsky bantuan yang tepat harusnya lebih banyak diberikan melalui pertanyaan-pertanyaan yang akan membawa anak untuk berpikir mencari jawaban sendiri. Prinsip ini dikenal dengan prinsip scaffolding (Halpern \& Donaghey, 2005).

Cara anak untuk mempelajari dunianya, baik dunia fisik maupun sosial, kita kenal dengan bermain. Pada awal kehidupannya anak banyak bermain hanya dengan lingkungan fisik atau pengasuhnya. Namun setelah melewati masa dua tahun maka anak mulai lebih banyak bermain dengan teman-teman sebanyanya. Melalui proses bermain itulah terjadi perkembangan kognitif, moral, emosional maupun sosial. Dengan demikian dunia belajar anak tidak dapat dilepaskan dari kata bermain (Ross \& Spielmacher, 2005).

\section{METODE}

Jenis penelitian ini adalah kualitatif etnografis. Tujuan penggunaan jenis penelitian ini adalah untuk mengeksplorasi secara deskriptif bagaimana kondisi budaya di kabupaten sumenep yang dapat memberikan dukungan atau hambatan terhadap proses belajar anak dalam bidang IPA. Subyek dalam penelitian ini meliputi beberapa anak yang dipilih secara acak purposif $\mathrm{Hal}$ utama yang menjadi pertimbangan pemilihan subyek penelitian ini adalah akses peneliti dan kesediaan mereka untuk diambil datanya mealui wawancara maupun observasi. Subyek dalam penelitian ini meliputi beberapa anak yang dipilih secara acak purposif.

Untuk memperoleh data mengenai gambaran budaya yang mendukung atau menghambat proses belajar anak pada bidang IPA di kabupaten Sumenep ini teknik pengumpulan data yang digunakan adalah Observasi dan Wawancara. Kedua teknik pengumpulan data ini diharapkan dapat saling melengkapi informasi yang dibutuhkan. Dalam melakukan kedua teknik tersebut, peneliti dibantu oleh informan kunci (key informant). Peran informan kunci yang memang diambil dari anggota asli masyarakat yang menjadi obyek penelitian adalah sebagai pemberi jalan bagi peneliti untuk menelusuri berbagai informasi penting mengenai kultur masyarakat. Selain itu, waktu penelitian yang tidak terlalu panjang membuat peneliti tidak dapat meleburkan diri (berpartisipasi) dengan kehidupan masyarakat yang diteliti sehingga kemungkinan besar jika peneliti melakukan observasi dan wawancara sendiri maka akan mendatangkan kecurigaan atau perasaan yang tidak nyaman bagi subyek yang diteliti. Pemakaian informan kunci ini diperbolehkan dalam penelitian kualitatif, tentunya dengan batasan-batasan dimana peneliti dapat memastikan bahwa tidak terdapat bias etnosentrisme dalam diri informan kunci tersebut.

Data hasil penelitian dianalisis dengan teknik analisis deskriptif, langkahlangkah analisis konten yang digunakan dalam penelitian ini adalah tahapan analisis konten menurut Neuman (2007) yang terdiri atas tiga langkah utama yaitu: 
Open coding, axial coding dan selective coding.

\section{Open Coding}

Tahapan yang pertama ini berisi proses katagorisasi data-data yang diperoleh dari observasi ataupun wawancara. Dua cara dapat digunakan dalam tahap ini yaitu aplikasi katagori secara deduktif atau pengembangan katagori secara induktif. Kedua cara tersebut juga dapat digunakan secara bersamaan untuk menghasilkan katagorisasi yang lebih lengkap. Dalam penelitian ini kedua cara tersebut digunakan secara bersamaan untuk menghasilkan katagorisasi berdasarkan teori mengenai budaya anak (deduktif) dan katagorisasi yang muncul dalam data yang didapatkan di dapangan.

2. Axial Coding

Tahap kedua setelah proses katagorisasi data selesai, tugas peneliti adalah mempelajari hasil katagorisasi data untuk kemudian mengorganisasikan data tersebut berdasarkan tema-tema kunci yang muncul. Kemunculan tema-tema kunci ini dapat diperoleh melalui pertanyaan-pertanyaan baru yang muncul ketika peneliti membaca kembali hasil organisasi data pada tahapan pertama, untuk kemudian mencoba mendapatkan jawaban tersebut melalui hubungan antar data pada katagori yang berbeda. Dalam axial coding ini juga ditentukan tingkatan-tingkatan data berdasarkan nilai pentingnya bagi tujuan penelitian.

3. Selective Coding

Seluruh katagori dan tema-tema kunci yang telah didapatkan dalam tahapan-tahapan sebelumnya diorganisasikan kembali pada tahapan terakhir ini untuk menghasilkan suatu generalisasi dengan penggabungan lebih dari satu katagori (sintesis). Tahap ini akan menyatukan konsepsi yang sebelumnya terpecah-pecah. Hasil dari proses terakhir ini dalam penelitian etnografi dapat berupa teoritisasi serta alur cerita (storyline) secara deskripstif mengenai gambaran budaya yang diteliti.

\section{HASIL DAN PEMBAHASAN Hasil}

Penelitian ini secara lebih spesifik memfokuskan perhatiannya terhadap kondisi kehidupan anak pesisir di Sumenep yang tergambarkan melalui aktivitas sehari-hari mereka. Melalui tiga lokasi penelitian (Desa Kertasada, Karanganyar dan Aengdake) peneliti mendapatkan temuan mengenai bagaimana anak-anak pesisir di Sumenep menjalani suatu pola kehidupan yang selaras dengan ritme profesi keluarga mereka, yaitu bagian dari masyarakat pesisir yang umumnya berprofesi sebagai nelayan, petani garam atau budidaya rumput laut.

Keseharian anak pesisir dengan profesi orang tua sebagai petani garam menunjukkan bahwa waktu-waktu mereka padat dengan pekerjaan-pekerjaan yang melengkapi dan turut berperan dalam menunjang keberhasilan orang tuanya dalam bertani garam. Selain itu, sebagai anak-anak tentunya mereka tidak bisa dipisahkan dari aktivitas bermain. Bermain jangkrik yang merupakan salah satu aktivitas bermain anak-anak di daerah pesisir Sumenep sebagai hasil temuan penelitian ini memberikan sebuah gambaran bagaimana hubungan antara aktivitas bermain anak dangan kondisi alam sekitarnya. Jangkrik merupakan serangga yang banyak sekali terdapat di berbagai daerah tidak hanya di Madura melainkan di seluruh Indonesia, sehingga bermain jangkrik ini banyak kita temukan pada daerah-daerah pertanian. Hal ini semakin menguatkan temuan pada bab pertama mengenai aktivitas anak dalam 
ritme profesi orang tua. Dalam bab ini jangkrik merupakan salah satu konsekuensi dari aktivitas anak sebagai bagian dari kehidupan orang tuanya yang berprofesi sebagai petani. Tentu saja selain bermain jangkrik, anak-anak tersebut juga memainkan permainan seperti kelereng, layangan atau lompat tali (permainan melompati tali yang terbuat ari untaian karet gelang dengan aturanaturan tertentu).

Bagaimana anak belajar, terutama ketika berada di rumah, didapatkan suatu gambaran bahwa anak-anak belajar di rumah hanya ketika mendapatkan tugas dari gurunya (PR). Belajar di rumah bagi mereka adalah mengerjakan tugas yang diberikan guru.

\section{Pembahasan}

Berdasarkan temuan dalam penelitian ini dapat digambarkan bagaimana posisi aktivitas harian anakanak pesisir di Sumenep jika dikaitkan dengan ritme aktivitas profesi orang tua mereka. Relasi tersebut dapat dilihat pada gambar

ini:

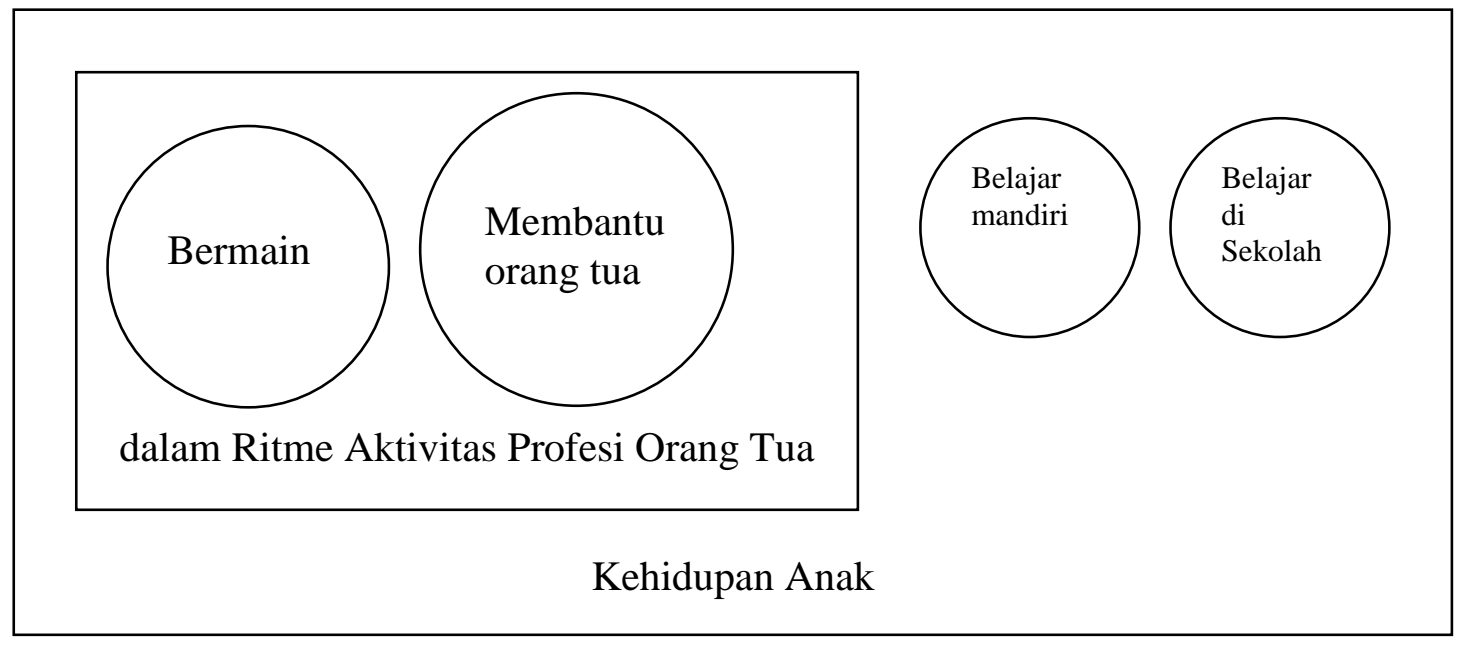

Gambar 1. Relasi Aktivitas Kehidupan Anak Pesisir dengan Ritme Aktivitas Profesi Orang Tua

Pada gambar 1 di atas terdapat gambaran bagaimana aktivitas anak (membantu orang tua dan bermain) berada di dalam ritme aktivitas profesi orang tua. Bagi petani garam maka diperoleh temuan bahwa aktivitas bermain anakpun juga berada dalam lingkungan yang berkaitan dengan profesi orang tua mereka sebagai petani garam, demikian pula yang terjadi pada anak yang orang tuanya berprofesi petani dan pencari rumput laut.

Bermain merupakan karakter dasar yang dimiliki oleh setiap anak di seluruh dunia. Satu daerah dengan daerah lain tentunya memiliki perbedaan karakter mengenai bagaimana kebiasaan dan pola bermain anak-anak di dalamnya. Namun yang jelas, bagaimana permainan anak tentunya juga sangat dipengaruhi oleh kondisi lingkungan yang menjadi tempat berbagai permainan dilaksanakan. Permainan anak-anak yang ditemukan pada ketiga daerah yang menjadi obyek penelitian adalah bermain jangkrik. Serangga dengan suara yang nyaring dan unik tersebut ternyata menjadi jenis permainan yang dilakukan oleh semua anak di ketiga daerah tersebut, tidak hanya oleh anak laki-laki namun juga oleh anak perempuan.

Cara anak untuk mempelajari dunianya, baik dunia fisik maupun sosial, kita kenal dengan bermain. Pada awal kehidupannya anak banyak bermain hanya dengan lingkungan fisik atau pengasuhnya. Namun setelah melewati 
masa dua tahun maka anak mulai lebih banyak bermain dengan teman-teman sebayanya. Melalui proses bermain itulah terjadi perkembangan kognitif, moral, emosional maupun sosial. Dengan demikian dunia belajar anak tidak dapat dilepaskan dari kata bermain (Ross \& Spielmacher, 2005). Dalam bermain jangkrik anak-anak di daerah pesisir Sumenep berinteraksi satu sama lain secara sosial dalam luapan emosi dan kegembiraan. Aturan-aturan sederhana yang mereka ikuti seperti bagaimana jangkrik yang bagus atau bagaimana proses jangkrik yang hendak diadu sedikit banyak membuat mereka mengenali aturan-aturan yang tidak datang langsung dari orang-orang yang lebih tua.

Aktivitas anak sebagai bagian dalam ritme aktivitas harian orang tua dalam penelitian ini dapat ditemukan secara kuat. Dalam ranah Sosiologi, keluarga memegang peranan penting bagi kehidupan anak. Keluarga merupakan ruang sosial pertama yang dikenal dan membentuk karakter sosial mereka. Dikarenakan peran inilah maka Cragun (2006) menyatakan

"If you want to know the
future of any society,
look on theways how
their children are raised,
and you will know the
future," yang artinya
adalah, jika anda ingin
mengetahui bagaimana
masa depan suatu
masyarakat maka lihat
saja bagaimana anak-
anak di masyarakat
tersebut dibesarkan,
maka akan akan
mengetahui bagaimana
masa depan mereka.

Selain permainan sebagai representasi dari relasi antara kehidupan anak dengan lingkungan (alam) sekitarnya, dalam penelitian ini juga ditemukan adanya pengaruh kemajuan teknologi dalam pola kehidupan bermain anak pesisir di Sumenep. Budaya-budaya dari luar Madura diimpor melalui teknologi informasi yang telah menyatu dengan kehidupan masyarakat yaitu televisi.

Dalam penelitian ini ditemukan selain bekerja membantu orang tua dan bermain, anak-anak di pesisir Sumenep memiliki aktivitas belajar. Yaitu belajar di sekolah dan belajar mandiri. Pada gambar tersebut peneliti menggambarkan aktivitas belajar ini sebagai dua buah lingkaran kecil jika dibandingkan dengan kedua aktivitas yang lain. Mengapa demikian? Hal ini didasarkan pada temuan penelitian mengenai bagaimana proporsi belajar anak jika dibandingkan dengan bekerja membantu orang tua ataupun bermain. anak-anak belajar di rumah hanya ketika mendapatkan tugas dari gurunya (PR). Belajar di rumah bagi mereka adalah mengerjakan tugas yang diberikan guru.

\section{KESIMPULAN DAN SARAN Kesimpulan}

Kehidupan anak pesisir di
Sumenep dalam penelitian ini menunjukkan suatu pola aktivitas yang sesuai dengan ritme profesi orang tuanya. Dalam hal ini umumnya adalah sebagai petani garam, nelayan, peternak atau petani tembakau. Pola bermain anak pesisir di Sumenep memiliki hubungan yang sangat kuat dengan kondisi alam sekitarnya (areal pertanian atau nelayan) seperti bermain jangkrik. Selain ini tren budaya dari luar Sumenep juga telah memasuki kehidupan anak-anak melalui berbagai acara TV yang hampir setiap malam mereka tonton. Porsi aktivitas belajar anak pesisir (dalam hal ini belajar IPA) masih minim. Umumnya belajar di rumah baru dilakukan ketika anak-anak mendapat tugas (PR) dari gurunya.

\section{Saran}

Kultur belajar anak di masyarakat pesisir dapat menjadi landasan bagi pengembangan model pembelajaran yang sesuai untuk diterapkan di sekolah.untuk 
itu dibutuhkan suatu informasi pelengkap mengenai bagaimana kondisi proses belajar mereka di sekolah setiap harinya. Pengembangan model pembelajaran berbasis kultur pesisir ini dapat dilakukan dengan menggunakan berbagai pendekatan. Adapun desain dan pengembangan model pembelajarannya dapat menggunakan penelitian $\mathrm{R} \& \mathrm{D}$ (Reasearch and Development).

\section{DAFTAR PUSTAKA}

Albrow, martin. 1999. Sociology, the basic. London: Routledge Publisher.

Badan Pusat Statistik Kabupaten Sumenep. 2009. Kabupaten Sumenep dalam Angka 2009. Sumenep: Badan Pusat Statistik.

Bungin, Burhan. 2009. Penelitian Kualitatif. Jakarta: Kencana Prenada Media Group.

Cragun, R. T. 2006. Introduction to Sociology. Cincinnati: University of Cincinnati.

Farenga, S.J. \& Ness, D. 2005. Jean Piaget. Encyclopedia of Education and Human Development. Vol. III. Hal: 949-952

Habibi. 2010. Pembelajaran IPA 1 . Sumenep: UNIJA PRESS.

Habibi, Anekawati, Anik \& Azizah, L.F. 2011.

Permasalahan

Pembelajaran IPA SMP/MTs di Kabupaten Sumenep 2010-2011. Sumenep: PRODI PENDIDIKAN IPA UNIJA

Halpern, D. F. \& Donaghey, B. 2005. Learning Theory. Encyclopedia of Education. Hal: 1458-1463

Neuman, W.L. 2007. Basic of Social Research, Qualitative and Quantitative Approach. Second Edition. Boston: Pearson Education, Inc.

Putra, Nusa. 2011. Penelitian Kualitatif: Proses dan Aplikasi. Jakarta: PT Indeks.
Ritchie, Jane. \& Lewis, Jane (ed.). 2003. Qualitative Research Practice, a Guide for Social Science Students and Researchers. London: Sage Publication.

Stolley, K.S. 2005. The Basics of Sociology. London: GREENWOOD PRESS

Taufiqurrahman. 2006. Islam dan Budaya Madura. Bahan presentasi pada forum Annual Conference on Contemporary Islamic Studies, Direktorat Pendidikan Tinggi Islam, Ditjen Pendidikan Islam, Departemen Agama RI, di Grand Hotel Lembang Bandung

Whitehead, T.L. 2005. Basic Classical Ethnographic Reasearch Methods. Maryland: CEHC. 